\title{
THE REVIEW AND REPUDIATION OF JUDGMENTS OF INTERNATIONAL ADMINISTRATIVE TRIBUNALS
}

\author{
Suzuki Eisuke*
}

A proliferation of international tribunals ${ }^{1}$ notwithstanding, no international administrative tribunal (IAT) provides a review process in the form of appeal to another tribunal. ${ }^{2}$ The archetypal provision of the finality of an IAT's judgement was Article VI of the Statute of the Administrative Tribunal of the League of Nations, which stipulated that "[t]he Tribunal shall take decisions by a majority vote; judgements shall be final and without appeal". The Statute of the Administrative Tribunal of the Asian Development Bank similarly states in Article IX that "[a]ll decisions of the Tribunal shall be taken by [a] majority vote and its judgements in each case shall be final and binding". The central theme running through a large number of statutes of IATs is the finality of judgements without appeal. $^{3}$

Each IAT's task is to settle internal disputes between the organization concerned and its staff within that organization's legal system. ${ }^{4}$ As it is an independent dispute resolution mechanism not only to safeguard the interests of staff members, but also the effectiveness of the organization concerned, respect for the tribunal and the effectiveness of its judgements hinge on its capacity for making accurate and right decisions as well as on its own internal discipline to correct its mistakes. In this connection, finality is a crucial element of stability in the internal legal order of the organization concerned. As a result, the rationality of law in repealing outdated legislation, amending an existing statute to

\footnotetext{
* Office of the General Counsel, Asian Development Bank. The views expressed herein are his personal views and do not necessarily reflect those of the Bank.

${ }^{1}$ See EliHU LAUTERPACHT, Aspects of the Administration of International Justice (1991) 9-22.

${ }^{2}$ As explained below, the review mechanism provided in either the ILO Tribunal or the UN Tribunal is not, in stricto senso, appeal to the ICJ. "There is no specific provision for any system of judicial appeal to the Court. It should be noted that establishing a system for review of judgments of administrative tribunals is an arrangement that must in no way be confused with an appeal system as such; it is clearly a review process and no more." T.O.ELIAS, 'The International Court of Justice in relation to the Administrative Tribunals of the United Nations and the International Labour Organization', in C. DE COOKER (ed.), International Administration (1990) V.4/1-2.

${ }^{3}$ The finality of judgments without appeal of IATs equals Art. 60 of the Statute of the International Court of Justice that "[t]he judgment is final and without appeal".

${ }^{4}$ See generally, C.F. AMERASINGHE, The Law of the International Civil Service as Applied by International Administrative Tribunals, Vols. I and II (2nd ed. 1995).
}

Asian Yearbook of International Law, Volume 7 (Ko Swan Sik et al., eds.

๑ Kluwer Law International; printed in the Netherlands), pp. 175-207 
accommodate changes through time, enjoining unauthorized administrative actions, nullifying defective arbitral awards, appealing wrong decisions to a higher adjudicative organ and ultimately calling for a community-wide referendum, is sadly lacking in IATs. "Yet," said Judge MANFRED LACHS of the International Court of Justice (ICJ), "no tribunal is infallible and occasionally questions were raised as to the correctness of its decisions". "It is a matter for serious thought and consideration", remarked Judge Sir ROBERT Y. JENNINGS, "whether more could be done to ensure that the principal judicial organ of the United Nations is the supreme court of the international community. . .".?

\title{
1. PROLOGUE
}

With the striking growth of international organizations, the ICJ has been drawn into performing an external 'supervisory jurisdiction' in the form of advisory opinion. ${ }^{8}$ 'Supervisory jurisdiction' refers to a type of jurisdiction

\begin{abstract}
"when the decision-maker is expected to respect the autonomy of another distinct and often structurally independent institution under supervision and to limit the enquiry to the ways the decisions were made in terms of certain preestablished prescriptions, for example, the competence of the entity under review, while refraining from substituting his or her own decision for that of the entity under supervision." [emphasis original $]^{9}$
\end{abstract}

The most elaborate form of supervisory function over IATs was set out in Article 11(1) of the Statute of the United Nations Administrative Tribunal (UNAT), which provided:

"If a Member State, the Secretary-General or the person in respect of whom a judgment has been rendered by the Tribunal (including any one who has succeeded to that person's rights on his death) objects to the judgment on the ground that the Tribunal has exceeded its jurisdiction or competence or that the

\footnotetext{
${ }^{5}$ Michael ReISMAN, "Revision of the South West Africa Cases", 7 Vanderbilt Journal of International Law no. 3 (1966) 5.

${ }^{6}$ Application for Review of Judgment No.273 of the United Nations Administrative Tribunal, ICJ Rep.1982: 325, 411 (dissenting opinion). See also REISMAN, loc.cit.n.5 at 5: "It seems inconceivable that the institutional procedures of the International Court of Justice should make no provision for human frailty and the rectification of errors, which even the most learned and best intentional officials of the world community might make".

${ }^{7}$ ROBERT Y. JENNINGS, "The United Nations at fifty: The International Court of Justice after fifty years', 89 AJIL (1995) 493, 504.

${ }^{8}$ See, e.g., Interpretation of the Agreement of 25 March 1951 between WHO and Egypt, ICJ Rep.1980: 73; Certain Expenses of the United Nations (Article 17, paragraph 2 of the Charter), ICJ Rep.1962: 151.

${ }^{9}$ W. MiCHAEL REISMAN, "The supervisory jurisdiction of the International Court of Justice: international arbitration and international adjudication', $258 \mathrm{RdC}(1996)$ 13, 24.
} 
Tribunal has failed to exercise jurisdiction vested in it, or has on a question of law relating to the provisions of the Charter of the United Nations, or has committed a fundamental error in procedure which was occasioned a failure of justice, such Member State, the Secretary-General or the person concerned may, within thirty days from the date of the judgment, make a written application to the Committee established by paragraph 4 of this article asking the Committee to request an advisory opinion of the International Court of Justice on the matter."

In the face of the growing confusion and criticism of the effectiveness and usefulness of the procedure for the supervisory function of the ICJ over the UNAT, in 1993 the United Nations General Assembly requested the SecretaryGeneral to carry out a review of the procedure provided for under Article 11 of the UNAT Statute. A Report of the Secretary-General, submitted to the General Assembly in October 1994, concluded that:

"the present review procedure, provided for under Article 11 of the statute of the Administrative Tribunal of the United Nations, has not proved to be a constructive and useful element of the appeal system available within the Secretariat. On the contrary, this procedure has caused confusion and criticism which supports the view that the best solution would be to abolish the current procedure." 10

The UN Secretary-General's Report thus confirmed the finality of the UNAT judgments by reiterating that "judgments of the Tribunal would be final and there would be no procedure which would allow the parties to the proceedings before the Tribunal to challenge its judgments."11

In the following year, as if endorsing the conclusion of the UN SecretaryGeneral's Report, Sir ROBERT JENNINGS, a former President of the ICJ, made the following devastating remarks in his plea "to ensure that the principal judicial organ of the United Nations is the supreme court of the international community, bearing in mind that a court which exists in isolation, however splendid, is not really in a position to be a supreme court in relation to other courts, as it does not have any formal relations with those other courts":

"Some mention should perhaps be made also of that part of the advisory jurisdiction which involved the review by the Court of questions arising from decisions of the United Nations Administrative Tribunal. This should, in the opinion of the writer, be abolished as soon as may be. To employ the World Court for this kind of work is not free from absurdity; furthermore the judges of that

\footnotetext{
${ }^{10}$ The Secretary-General's Report on Review of the procedure provided for under Article 11 of the Statute of the Administrative Tribunal of the United Nations, UN Doc.A/C.6/49/2 para.37.

"Ibid.
} 
Court have no expertise, and often no great interest, in that highly specialized corner of labour law." 12

The 'specialized' aspects of IATs relate only to their jurisdiction and structure, none of which can be considered a matter so 'specialized' as to preclude the supervisory jurisdiction of another appropriate tribunal. In particular, when each IAT is embedded with its own structural limitations that it is created and organized 'within' the same system, the need for a broader supervisory function external to IATs is obvious. ${ }^{13}$

Instead of trying to improve the existing procedure provided for under Article 11 of the UNAT Statute in such a way as to make it "a constructive or useful element in the adjudication of staff disputes within the Organization", the General Assembly decided to abolish the review procedure by deleting in toto Article 11 of the Statute in December $1995 .^{14}$ As a result, there has been no appeal or review with respect to judgments rendered by the UNAT after 31 December 1995. Up to the date of the Secretary-General's Report of 17 October 1994, the Committee on Applications considered 92 cases, but only in three cases has the Committee decided to request an advisory opinion of the ICJ. ${ }^{15}$ The latest amendment of the UNAT Statute made no review possible. The baby was thrown out with the bath water!

This article examines the tension between authoritative expectations about finality on the one hand and effective demands for review in the decisions of IATs on the other; analyzes the instances in which those decisions were subjected to review by any body other than the concerned IAT itself; and recommends certain structural changes to the international system of IATs. ${ }^{16}$

\footnotetext{
${ }^{12}$ Jennings, loc.cit.n.7 at 503. Cf. Judge PIERRE PESCATORE's views of the ICJ, infra n.153.

${ }^{13}$ I am mindful of Judge MBAYE's admonition in the Arbitral Award of 31 July 1989 on the danger of constituting the ICJ as a court of appeal after the completion of arbitration between states, but the nature of the supervisory function that can be fashioned by the ICJ over judgments of IATs is substantially different from Judge MBAYE's concerns. Judge MBAYE's declaration reads in part: "I fail to see why the International Court of Justice should automatically constitute itself as a cour de cassation for all States having made declarations under Article 36, paragraph 2, of its Statute, with respect to all arbitral awards in cases to which those States are parties, even if the Court were each time to take care not to act as a court of appeal or as one revising the award. That the need to decide a "question of international law" has been raised is surely not sufficient justification for such an inroad into another means of settlement of disputes between States. To deny this would be to embark on an adventure which would have disastrous consequences not confined to arbitral decisions. The court has fortunately refused to take this path." ICJ Rep.1991: 53,80 (declaration of Judge MBAYE).

${ }^{14}$ UNGA Res. 50/54 of 11 Dec.1995. See HUBERT THIERRY, "Some changes in international administrative justice", 90 ASIL Proc.1996 at 329.

${ }^{15}$ Secretary-General's Report, loc.cit.n.10 at para.8.

${ }^{16}$ PIERRE PESCATORE, "Two Tribunals and One Court: some current problems of international administration in the jurisdiction of the ILO and UN Administrative Tribunals and the International Court of Justice', in NIELS BLOKKER and SAM MULLER (eds.), Toward more effective supervision by international organizations: Essays in honour of Henry G. Schermers Vol.1 (1994) 217 ; JOAMA GOMULA, "The International Court of Justice and administrative tribunals
} 


\section{THE PURPOSE AND EFFECT OF THE FINALITY OF THE JUDGEMENTS OF IATS}

Various immunities and privileges accorded to international organizations are designed to ensure the independence and autonomy of these organizations. The effect of these immunities and privileges in preserving the exclusively international character of the organizations and their staff is that national law is not applicable to the organizations if it would impede the independent operations and functions of the organizations. ${ }^{17}$ The relations between the staff members and the organizations are governed by a complex code of internal law consisting of, e.g., the Staff Regulations adopted by the General Assembly and the Staff Rules made by the Secretary-General for the implementation of the Staff Regulations. ${ }^{18}$ As the ICJ acknowledged in Effect of Awards, "[i]t was inevitable that there would be disputes between the Organization and staff members as to their rights and duties". ${ }^{19}$ But staff members do not have recourse to the jurisdiction of national courts, from which the organization is immune. ${ }^{20}$ As one commentator put it, "[t]here is therefore a vacuum which needs to be filled by the organizations themselves." 21

of international organizations", 13 Michigan Journal of International Law (1991) 83; T.O. ELIAS, New horizons in international law (1992) 327; RUDOLF OSTRIHANSKY, "Advisory opinions of the International Court of Justice as reviews of international administrative tribunals", 17 Polish Yearbook of International Law (1988) 101; and WOOSANG CHOI, "Judicial review of international administrative tribunal judgments", in THOMAS BUERGENTHAL (ed.), Contemporary issues in international law: Essays in honor of Louis B. Sohn (1984) 347.

${ }^{17}$ See C.WILFRED JENKS, International immunities (1961). For the most recent treatment of the subject, see SEGVEI TARASSENKO and RALPH ZACKLIN, "Independence of international civil servants (privileges and immunities)", in DE COOKER, op.cit.n.2, at III.1/1. See also: Respect for the privileges and immunities of officials of the United Nations and the Specialized Agencies, UN Doc.A/C.5/36/31, 4 November 1981.

${ }^{18}$ The ADB Administrative Tribunal (ADBAT) outlined "the principal rules of law within the framework of which the facts must be considered" as follows: "In addition to the constituent instruments of the Bank and of the Tribunal, as well as general principles of law, these rules are to be derived from the contract between the Bank and the staff member, the Staff Rules and Regulations of the Bank, the Personnel Handbooks for professional and support staff, and Administrative Orders and Circulars, as promulgated and applied from time to time, subject to other recognition and protection of any acquired right of the staff, and, by analogy, from the staff practices of international organizations generally, including the decisions of international administrative tribunals dealing with comparable situations." Further, the ADBAT stated: "There is, in this sphere, a large measure of "common" law of international organizations to which, according to the circumstances, the Tribunal will give due weight." Carl Gene Lindsey v. Asian Development Bank, Decision No.1, para.4 (1992), 1 ADBAT Rep.(1997) 1.

${ }^{19}$ Effect of Awards of Compensation Made by the United Nations Administrative Tribunal, ICJ Rep.1954: 47, 57.

${ }^{20}$ See e.g. Broadbent v. Organization of American States, 628 F.2d 27 (D.C. Cir. 1980): "[T]he special nature of the law governing employment in international organizations, clearly linked as it is with delicate questions of administrative policy, makes municipal tribunals totally unsuited to deal with it". Ibid. at 35 n.27.

${ }^{21}$ MiChAEL B. AKEHURST, "The law governing employment", 12 International Organization 
"The creation of an independent body, empowered to make binding decisions in legal disputes between an organization and its staff, is by no means an altruistic gesture from the organization's point of view; without it, officials might suffer from a sense of injustice which would impair the smooth running of the Secretariat." 22

"In these circumstances", said the ICJ in Effect of Awards, "the Court finds that the power to establish a tribunal, to do justice as between the Organization and the staff members, was essential to ensure the efficient working of the Secretariat, and to give effect to the paramount consideration of securing the highest standards of efficiency, competence and integrity." 23

10. The omission of an institutionalized review process derives not so much from the status of international organizations enjoying immunity from national jurisdiction as from the desire of international organizations' effective authorities that internal employment disputes should be settled expeditiously to avoid vexatious proceedings. The report of the Supervisory Commission, proposing the Statute of the Administrative Tribunal of the League of Nations, clearly explains that the omission of any provision for a review of judgements was deliberate:

"No provision for the revision of judgements of the Tribunal is inserted in the statute. It is considered that, in the interests of finality and of the avoidance of vexatious proceedings, the Tribunal's judgements should be final and without appeal. ..." 24

(1967). In Broadbent v. Organization of American States, the Circuit Court approvingly quoted this passage in its opinion. Ibid.

${ }^{22}$ Ibid.

${ }^{23}$ Effect of Awards, loc.cit.n.19 at 57. Given the vast discretionary powers vested in the General Assembly and the Secretary-General, a tribunal is a control system. In the beginning, the ICJ attributed the establishment of an administrative tribunal to the implied powers under Art.101 of the UN Charter (Effect of Awards, loc.cit.n.19 at 47, 58), but see the dissenting opinion of Judge HACKWORTH: "The doctrine of implied powers is designed to implement, within reasonable limitations, and not to supplant or vary, expressed powers. The General Assembly was given express authority by Article 22 of the Charter to establish such subsidiary organs as might be necessary for the performance of its functions whether those functions should relate to Article 101 or to any other Article in the Charter. Under this authorization the Assembly may establish any tribunal needed for the implementation of its functions." Ibid. at 80 . Cf. Review of Judgment No. 273 of the United Nations Administrative Tribunal (ICJ Rep. 1982 at 325) in which the ICJ unequivocally confirmed the subordinate status of the UNAT, stating that: "Certainly the Tribunal must accept and apply the decisions of the General Assembly made in accordance with Article 101 of the United Nations Charter. Certainly there can be no question of the Tribunal possessing any 'powers of judicial review or appeal in respect of the decisions' taken by the General Assembly, powers which the Court itself does not possess (ICJ Reports 1971, p. 45, para. 89). Nor did the Tribunal suppose that it had any such competence". Ibid. at 363. For a succinct overview and analysis of the legal bases of IATs, see GOMULA, loc.cit.n.16 at 88-94.

${ }^{24} 9$ League of Nations Official Journal, Special Supplement No.58 (1928) 254. 
Likewise, the original UNAT Statute did not contain any provision for review of the judgements of that Tribunal. The Official Records of the Fifth Committee of the General Assembly shows that in an exchange between the representative of Belgium and the rapporteur of that Committee, the former asked the rapporteur "whether the decisions of the administrative tribunal would be final or whether they would be subject to a revision by the General Assembly." The rapporteur replied:

"[A]ccording to the draft Statute as prepared by the Advisory Committee, there could be no appeal from the administrative tribunal. The Advisory Committee feared an adverse effect on the morale of the staff if appeal beyond the administrative tribunal delayed the final decision in a case which had already been heard before organs within the Secretariat created for that purpose." 25

Other IATs established after the UNAT have invariably followed the same deliberate omission of any provision for review. The original intention and good faith in the proper functioning of an administrative mechanism for dispute settlement, however, did not always bear agreeable results reflecting the expectations and interests of effective elites of their respective organizations. The absence of review or appeal has, on occasion, caused institutional and financial crises in certain international organizations.

Law is a process of authoritative decision designed to maximize good things and to minimize bad things within a given group, be it territorially or functionally organized. ${ }^{26}$ Any such group seeks to maintain such level of minimum order within as to maintain a reasonable degree of stability that enables group members to engage in sustained productive activities through time. Group demands for stability will create, over time, expectations about the finality of an authoritative decision when it is supported by sufficient effective power holders. ${ }^{27}$ Effective decisions and authoritative decisions, however, are the products of two different processes of decision: an authoritative process may invoke the doctrine of res judicata, a general principle of law that a judgement rendered by a judicial body is final, whilst an effective power process may claim that a judgement was rendered by an excès de pouvoir and refuse to comply with the determination made by the authoritative process. ${ }^{28}$ To

${ }^{25}$ Quoted in 'Effect of Awards', loc.cit.n.19 at 54.

${ }^{26}$ H.LASSWELL and M.MCDOUGAL, Jurisprudence for a free society: studies in law, science and policy (1992); M.MCDOUGAL, H.LASSWELL and W.M.REISMAN, "Theories about international law: prologue to a configurative jurisprudence", 8 VirgJIL (1973) 188; M.MCDOUGAL, H.LASSWELL and W.M.REISMAN, "The world constitutive process of authoritative decision", in C.BLACK and R.FALK (eds.), The future of the international legal order, Vol.1 (1969) 73; and M.MCDOUGAL, H LASSWELL and L.CHEN, Human rights and world public order: the basic policies of an international law of human dignity (1980).

${ }^{27}$ W.MICHAEL REISMAN, Nullity and Revision: the review and enforcement of international judgments and awards (1971) 171-186.

${ }_{28}^{28}$ See, e.g., Arbitral Award Made by the King of Spain on 23 December 1906 (Honduras $v$. Nicaragua), 1960 ICJ Rep.192. 
be effective and controlling, therefore, an authoritative decision must be backed up by effective power. ${ }^{29}$ Law, after all, is a delicate balance of authority and control. As MICHAEL REISMAN remarked:

"Repudiation or attempted repudiation of an authoritative decision does not in-
variably follow every decision that contravenes the interests of a particular con-
trolling group. Adverse decisions that do not mean serious shifts in power allo-
cation are usually accepted; their sting is not so intense as to blind the victim's
recognition of the common benefits in a working decision process. Authority
has ventured somewhat outside the perimeter of control but has not crossed that
Rubicon beyond which its own effectiveness is imperilled."

General international tribunals established by a compromis and discharging their respective functions within a context of low institutionalization know their authority is tenuous and their judgements are susceptible to a threat of repudiation. IATs, on the other hand, are created as permanent judicial bodies under special statutes of the organizations concerned and function within an organized and highly institutionalized context. According to the ICJ, therefore, the question of the nullity of the arbitral awards made in the ordinary course of arbitration between states does not apply to the judgements of international administrative tribunals functioning within a different legal situation. It stated in its Advisory Opinion on Effect of Awards:

"This problem would not, as has been suggested, raise the question of the nullity of arbitral awards made in the ordinary course of arbitration between States. The present Advisory Opinion deals with judgements pronounced by a permanent judicial tribunal established by the General Assembly, functioning under a special statute within the organized legal system of the United Nations, and dealing exclusively with the internal disputes between the members of the staff and the United Nations represented by the Secretary General. In order that the judgements pronounced by such a judicial tribunal could be subjected to review by any body other than the tribunal itself, it would be necessary, in the opinion of the Court, that the statute of that tribunal or some other legal instrument governing it should contain an express provision to that effect. The General Assembly has the power to amend the Statute of the Administrative Tribunal by virtue of Article 11 of that Statute and to provide for means of redress by another organ. But as no such provisions are inserted in the present Statute, there is no legal ground upon which the General Assembly could proceed to review judgements already pronounced by that Tribunal." 31

Despite the strong presumption of finality in the judgements of IATs, effective power holders continue to underpin traditional views that an arbitral award, though final and without appeal, may be vitiated by defects which make

\footnotetext{
${ }^{29}$ REISMAN, op.cit.n. 27 at $146-154$.

${ }^{30}$ Ibid. at 173 .

${ }^{31}$ 'Effect of Awards', loc.cit.n.19 at 56.
} 
it void. ${ }^{32}$ Thus, the ICJ's initial assertion of the immunity of the UNAT's decisions from review notwithstanding, it did not go so far as to state that all decisions of the UNAT were valid. ${ }^{33}$ On the contrary, the validity of the Tribunal's decision was qualified by the UNAT being "properly constituted and acting within the limits of its statutory competence" ${ }^{34}$ In terms of substantive outcomes, therefore, there will be no difference between the finding of an act ultra vires of the UNAT not properly constituted and not acting within the limits of the statutory competence on the one hand and the finding of a traditional ground of nullity on the other. ${ }^{35}$

\section{JURISDICTION OF LIMITED POWERS AND NULLITY IN INTERNATIONAL LAW}

All IATs' jurisdiction and competence are limited by their respective statutes, as the Administrative Tribunal of the Asian Development Bank (ADBAT) stated in its recent decision in Cynthia Bares et al. v. the Bank: ${ }^{36}$

\footnotetext{
${ }^{32}$ See Judge WINIARSKI's separate opinion: "I can see no difference between the nullity of an arbitral award and that of an award made by the Administrative Tribunal. An arbitral award, which is always final and without appeal, may be vitiated by defects which make it void; in this event, a party to the arbitration will be justified in refusing to give effect to it. This is not by virtue of any rule peculiar to ordinary arbitration between States; it is a natural and inevitable application of a general principle existing in all law: not only a judgment, but any act is incapable of producing legal effects if it is legally null and void. The Administrative Tribunal, organized as it is, for important practical reasons, is a permanent tribunal made available by the United Nations and accepted by staff members under a contract freely entered into. It does not and cannot constitute an exception to the general rule. . . . There can be no appellate procedure in the absence of an express provision which must in the first place establish an appellate tribunal. But appeal is one thing, and refusal to give effect to a judgment which is a nullity is another. The view that it is only possible for a party to rely on the rule relating to nullities where some procedure for this purpose is established, finds no support in international law. . . . [T] he absence of an organized procedure does not do away with nullities, and there is no warrant for the idea that there can be no nullity if there is no appropriate court to take cognizanxes of it. Nor is it necessary that the principle, in accordance with which a party is entitled to refuse to give effect to a judgment which legally is a nullity, should be enunciated in any express provision." Ibid. at 65 .

${ }^{33}$ REISMAN, loc.cit.n.5 at 15.

${ }^{34}$ 'Effect of Awards', loc.cit.n.19 at 55.

${ }^{35}$ Arbitral Award of 31 July 1989 (Guinea-Bissau v. Senegal), ICJ Rep.1991: 53, 108-109: "Excès de pouvoir is one of the most invoked rubrics of nullity and one of the areas where arbitral law will continue to face challenges and require development. Although the Parties, both of civil law jurisdictions, preferred to couch their arguments in terms of excès de pouvoir, similar concepts of total nullity find a place in the jurisprudence of other legal systems, including common law, where the concept of ultra vires has recently received extended development in the context of administrative and arbitral law." (dissenting opinion of Judge WEERAMANTRY)

${ }^{36}$ Decision No. 5 [1995], 1 ADBAT Rep.53.
} 
"The Tribunal is not akin to one of general jurisdiction within the national sphere. Here the proceedings are controlled entirely by the Statute of the Tribunal as promulgated by the Bank. Whatever is done by or in this Tribunal can be done only in accordance with that Statute. Article II, paragraph 1, of this prescribes that the Tribunal may deal only with an application which 'alleges nonobservance of the contract of employment or terms of appointment' of a staff member." 37

Thus, the ADBAT stated that "the limitation upon the jurisdiction of this Tribunal is laid down in its Statute which is binding upon both the Tribunal and the Bank's administration". ${ }^{38}$ The question of nullity of judicial or arbitral decisions in international law is more serious in other general international tribunals as they are, in the words of Judge JOHN BASSETT MOORE, "of limited powers". ${ }^{39}$ They are created by the consent of those equal and sovereign states. IATs also share the same fundamental issues relating to the question of nullity of their decisions as they are of equally limited powers prescribed in their respective statutory instruments. ${ }^{40}$

Article III of the Statute of the ADBAT provides that "[a]ny issue concerning the competence or jurisdiction of the Tribunal shall be settled by the Tribunal in accordance with this Statute" [emphasis added]. The ADBAT is thus endowed with the competence to decide its own competence, and accordingly, the ADBAT has acted "in the exercise of its inherent jurisdiction" [emphasis added] in Peter Nelson v. the Bank. ${ }^{41}$ Nevertheless, the so-called compétence de la compétence cannot possibly mean that an IAT is the final and absolute judge of its own jurisdiction subject to no limitations. As the historical origin of the doctrine compétence de la compétence attests, it was designed to protect the interest of the adjudicative or arbitral process without taking cumbersome and disruptive steps of trying to obtain the consent of the parties each

\footnotetext{
${ }^{37}$ Ibid. at para. 11 .

${ }^{38}$ Ibid. at para. 12 .

${ }^{39}$ Judge MOORE's classic statement: "Ever mindful of the tact that their judgments, if rendered in excess of power, may be treated as null, international tribunals have universally regarded the question of jurisdiction as fundamental. . . . The international judicial tribunals so far created have been tribunals of limited powers. Therefore no presumption in favor of their jurisdiction may be indulged. Their jurisdiction must always affirmatively appear on the face of the record." Mavrommatis Palestine Concession, Judgment No. 2, PCIJ Ser.A No.2 at 60.

${ }^{40}$ For the different types of nullity under international law, see R.Y. JENNINGS, "Nullity and effectiveness in international law", in Cambridge essays in international law: Essays in honour of Lord McNair (1965) 65-67.

${ }^{41}$ Decision No.7 [1995], at para. 22. See Nottebohm (preliminary objection), ICJ Rep.1953 at 119: "... a rule consistently accepted by general international law in the matter of international arbitration. Since the Alabama case, it has been generally recognized, following the earlier precedents, that, in the absence of any agreement to the contrary, an international tribunal has the right to decide as to its own jurisdiction and has the power to interpret for this purpose the instruments which govern that jurisdiction."
} 
time in order to determine whether or not a particular matter was within the competence or jurisdiction of an ad hoc tribunal to decide. ${ }^{42}$

With limited jurisdiction and limited competence, the absence of a review or appeal process in the statute of the IAT is saddled with contradictory propositions: one proposition clearly implies that an IAT cannot take action outside the limited scope of jurisdiction and competence prescribed in the statute; the other proposition states that "[w]hatever is done by or in this Tribunal" ${ }^{43}$ cannot be reviewed or appealed. The combined effect of these contradictory propositions is to defy the basic notion that flesh and blood human beings sometimes make an error in decision. Judge LACHS warned that "no tribunal is infallible" ${ }^{44}$ Given that, "[t]o contend that their decisions are not reversible is to render limited powers limitless and to validate any excess of jurisdiction through the mere formality of handing down a judgement". ${ }^{45}$

No provision for a supervisory function by an external institution was included in the statutes of these administrative tribunals for fear of an adverse effect on the morale of the staff unless vexatious proceedings were avoided. Concerns for expeditious proceedings with finality averted an inquiry into the structural limitations embedded in each IAT, i.e., it was an institution within the system. Moreover, this sole focus on the interest of the staff poses a dilemma for effective power holders of the organizations because:

"[t]he right of review is the prerogative of final decision. This is a question of power. Insofar as patterns of authority reflect the interests of effective elites, the latter can be expected to cede final decision to authoritative processes. When, however, effective elites consider an authoritative decision divergent from their interests, they can be expected to assert their power to modify or nullify the decision or to realign the decision process as a whole. ${ }^{46}$

In the absence of a supervisory jurisdiction to be exercised by an external authority over the judgments of an IAT, how can the interests of staff members be protected against organizational imperatives ${ }^{47}$ or how do the effective elites

${ }^{42}$ See also I. SHIHATA, The power of the International Court to determine its own jurisdictions. Compétence de la compétence (1965). W. MICHAEL REISMAN, Systems of control in international adjudication and arbitration (1992).

${ }^{43}$ Loc.cit.n. 35 at para. 11.

${ }^{44}$ ICJ Rep.1982 at 411, para. 1 (dissenting opinion of Judge LACHS).

${ }^{45}$ REISMAN, loc.cit.n.5 at 13. See also Arbitral Award of 31 July 1989 (Guinea-Bissau v. Senegal), ICJ Rep.1991: 53, 119 (separate opinion of Judge SHAHABUDDEEN): “The international arbitral process provides a useful procedure of peaceful settlement. The international community rightfully values the process. Clearly its entity must be protected against open-ended challenges to the finality of awards. Equally clear, it would be misconceived to seek to protect the system by suffering any serious fault in its operation to remain remediless: the preservation of the system and the vindication of its credibility are interlinked." See also C.F.AMERASINGHE, "The "future of international administrative law", 45 ICLQ (1996) 773, 782-785.

${ }^{46}$ REISMAN, op.cit.n.27 at 71 .

${ }^{47}$ REISMAN, loc.cit.n.9 at 34: "If the organizations are undergoing radical changes, for exam- 
of the organization realign the decision process in response to an authoritative decision that they consider divergent from their interests?

\section{PAST RESPONSES BY INTERNATIONAL ORGANIZATIONS}

Both the International Labour Organisation (ILO) and the United Nations each realigned its decision process by amending its respective Administrative Tribunal's Statute so as to provide a review process in which effective groups' legitimate interests can be protected. But no organization would ask for a review of a judgment when the judgment concerned was in its favor. Where would the individual staff member concerned who lost the case go for appeal?

\subsection{International Labour Organisation}

At the outbreak of World War II, by a resolution of December 14, 1939, the Assembly of the League of Nations amended the Staff Regulations of employees of the League and the ILO by authorizing the Secretary-General of the League to shorten notice of termination from six months to one month and to extend the period of compensation over four annual installments, not, as before, in one payment. ${ }^{48}$ Twelve officials of the Secretariat and one official of the ILO, whose contracts were terminated under the December 14, 1939 resolution of the League, complained to the Administrative Tribunal of the League of Nations (LNAT) that their contracts could not be modified unilaterally by decisions of the Assembly. ${ }^{49}$

The Secretary-General of the League of Nations contended that the LNAT had no jurisdiction on the ground that decisions of the Assembly were not subject to its review. The LNAT, however, upheld the complainants' cases, stating the LNAT's competence "to hear complaints alleging non-observance, in substance or in form, of the terms of appointment of officials" implies "the attribution of full competence in respect of the execution of all contractual obligations entered into by the League of Nations towards its officials, and no distinction whatsoever is made between an act of the Assembly itself and an act of the agents whom it invests with authority over the staff" ${ }^{50}$ It concluded that " $[t]$ he Staff Regulations of the Secretariat, as in force at the date of the com-

ple, 'downsizing', a supervision for dismissing significant numbers of employees without regard to the quality of their performance but in the interests of organization efficiency, then the administrative tribunals, may not be the bulwark for the protection of employee rights."

${ }^{48} 20$ League of Nations Official Journal, Part I at 424.

${ }^{49} 13$ Annual Digest 199. See also FRANK GUTTERIDGE, "The ILO Administrative Tribunal”, in DE COOKER (ed.), op.cit.n.2 at V.2/3-5.

${ }^{50}$ League of Nations Official Journal, Supplement No.107 at 206. 
plainant's contract, formed part of the terms of that contract" under which "the complainant had an acquired right". ${ }^{51}$

As the LNAT was not convened until 1946 due to World War II, its emphasis on the contractual terms prior to 1932 as against the crisis situation developing in 1939 when World War II broke out completely ignored the time factor of the in-between period during which the crisis abated. The LNAT's refusal to consider the effects of crisis rendered the award unacceptable to effective power holders of the League of Nations. The Supervisory Commission declined to take the responsibility for recommending payment of the awards on the ground that "an acceptance of the findings of the Administrative Tribunal would put its decision above the authority of the Assembly". ${ }^{52}$ The Assembly met in April, 1946 and the Second (Finance) Committee set up a Subcommittee to consider the matter. The Sub-Committee characterized the LNAT's reasoning as an "excessively static legal view" and reported that:

"it seems to us impossible to suppose that, in no circumstances, however pressing the necessity in the interests of the peoples of the world, could the League derogate from some contract to a private individual employed by it." ${ }^{\text {"S3 }}$

Accordingly, the report of the Sub-Committee concluded:

- "Although there is no ordinary appeal for the Tribunal's decision, we think that it is within the power of the Assembly, which can best interpret its own decisions, by a legislative resolution, to declare that the awards made by the Tribunal are invalid and are of no effect both because they sought to set aside the Assembly's legislative act and because of their mistaken conclusion as to the intention of that act." 54

The Sub-Committee's report was adopted by the Second (Finance) Committee and the Assembly of the League of Nations then adopted the report of the Second (Finance) Committee. ${ }^{55}$ Thus, repudiation of the LNAT's decision became complete. Several years later the ICJ wryly remarked in connection with Effects of Awards that "[i]t is unnecessary to consider the question whether the Assembly, which in very special circumstances was winding up the League, was justified in rejecting those awards" ${ }^{56}$ [Emphasis added]

The League of Nations was liquidated in 1946. The International Labour Conference, acting upon the League's request, reconstituted the LNAT under the new name "Administrative Tribunal of the International Labour Organization" (ILOAT), with a few modifications to its Statute on October 9, 1946. The

\footnotetext{
${ }^{51}$ League of Nations Official Journal, Special Supplement No.194 at 245.

${ }^{52}$ Ibid. at 162, Annex 8.

${ }^{53}$ Ibid. at 262, Annex 26.

${ }^{54}$ Ibid. at 263, Annex 26.

${ }^{55}$ Ibid. at 133.

56 'Effect of Awards', loc.cit.n.19 at 62.
} 
ILOAT Statute was amended by the International Labour Conference on June 23, 1949, which subsequently became Article XII of the ILOAT Statute:

" 1 . In any case in which the Executive Board of an international organization which has made the declaration specified in Article II, paragraph 5, of the Statute of the Tribunal challenges a decision of the Tribunal confirming its jurisdiction, or considers that a decision of the Tribunal is vitiated by a fundamental fault in the procedure followed, the question of the validity of the decision given by the Tribunal shall be submitted by the Executive Board concerned, for an advisory opinion, to the International Court of Justice.

2. The opinion of the Court shall be binding."

It not only provided, for the first time, a supervisory mechanism by way of a request for an advisory opinion from the ICJ, but also made the ICJ's advisory opinion binding upon the parties to the dispute before a different tribunal. ${ }^{57}$

The Executive Board's first challenge to a decision rendered by the ILOAT under Article XII of the ILOAT Statute was made in November, 1955 with respect to the Leff, Duberg, Wilcox and Bernstein cases. ${ }^{58}$ These cases involved Executive Order No. 10.422 of January 9, 1953 whereby the President of the United States established machinery and procedures for the investigation of possible subversive activities against the United States by United States citizens employed or being considered for employment by the United Nations and the communication of the results of such investigation to the Secretary-General of the United Nations. All these complainants separately refused to answer a questionnaire for the purpose of this investigation and refused to reply to an interrogatory from the International Organizations Employees Loyalty Board of the United States Civil Service Commission. The Director-General of UNESCO refused to renew their fixed-term contracts on the ground of a lack of integrity in connectionn with the complainants' refusal to appear before the Loyalty Board. ${ }^{59}$

\footnotetext{
57 "The introduction of this procedural device was a most astute move, because whenever the execution of a judgment of the tribunal meets with resistance from an organization (or its member states, which at the end comes to the same thing) it places the governing body of this organization before an incapable alternative: either accept the judgment and execute it, or else bring the matter before the International Court of Justice and accept in advance its ruling as binding." PESCATORE, loc.cit.n.16 at 222.

${ }^{58}$ In re Duberg, Judgment No.17 of 26 April 1955; In re Leff, Judgment No.18 of 26 April 1955; In re Wilcox, Judgment No.19 of 26 April 1955; and In re Bernstein, Judgment No.21 of 29 October 1955, all of the ILOAT.

${ }^{59}$ With respect to the appearance of United States citizens employed by the United Nations and by the specialized agencies before United States Federal Grand Jury and Congressional Committees and the investigations of the loyalty of such oficials by United States Government agencies, see 20 ILR 505.
} 
In its advisory opinion on Judgements of the Administrative Tribunal of the ILO upon Complaints made against the UNESCO (Unesco), ${ }^{60}$ the ICJ considered whether the use of the advisory jurisdiction of the ICJ for the judicial review of contentious proceedings which had taken place before other tribunals and to which individuals were parties, was compatible with the provisions of the UN Charter and the ICJ Statute, and with the requirement of the judicial process. ${ }^{61}$

The ICJ faced the question of equality between UNESCO and the officials again in connection with the actual procedure before it because the absence of equality became manifest from the provision of the ICJ Statute which precludes participation of individuals before the Court. The principle of equality of the parties, pursuant to Article 35(2) of the ICJ Statute, flows from "the requirements of good administration" ${ }^{62}$ The ICJ managed to rectify the procedural inequality of the parties by adopting the procedure under which the written statement of the officials were submitted to the Court through Unesco and by dispensing with oral proceedings. The ICJ thus concluded "[a]ny seeming or nominal absence of equality ought not to be allowed to obscure or to defeat" the primary purpose of lending advisory assistance to "the working of the regime established by the Statute of the Administrative Tribunal for the judicial protection of officials." 63

The ICJ's advisory opinion is expressly made binding under Article XII of the ILOAT Statute, and such effect of the advisory opinion would exceed the scope attributed by the UN Charter and the ICJ Statute. ${ }^{64}$ The ICJ acknowledged that " $[t]$ he advisory procedure thus brought into being appears as serv-

${ }^{60}$ Unesco, ICJ Rep.1956: 77. The fundamental basis of authority for an advisory opinion is Art.96 of the UN Charter:

"1. The General Assembly or the Security Council may request the International Court

of Justice to give an advisory opinion on any legal question.

2. Other organs of the United Nations and specialized agencies, which may at any time be so authorized by the General Assembly, may also request advisory opinions of the

Court on legal questions arising within the scope of their activities."

Likewise, Article 65, paragraph 1, of the ICJ Statute provides: "The Court may give an advisory opinion on any legal question at the request of whatever body may be authorized by or in accordance with the Charter of the United Nations to make such a request." The effect of these separate provisions has enabled the ICJ to establish that its power to give an advisory opinion under Article 65, paragraph 1, of the ICJ Statute is "permissive" and "that power is of a discretionary character" (ICJ Rep.1973 at 21, para.23). Moreover, the ICJ considers its reply to a request for opinion "its participation in the activities of the United Nations" and, therefore, such request, "in principle, should not be refused" (ICJ Rep.1987 at 31, para. 25).

${ }^{61}$ Unesco, loc.cit.n.60 at 84-86.

${ }^{62}$ Ibid. at 86.

${ }^{63}$ Ibid. According to Professor E.LAUTERPACHT, "the Court chose to adopt an interpretation conferring upon itself greater scope of action, on the basis that this was necessary for the full achievement of the objectives of the regime governing the relationships between international organizations and their staff." E.LAUTERPACHT, "The development of the law of international organizations by the decisions of international tribunals", $152 \operatorname{RdC}(1996) 379,421$.

${ }^{64}$ Unesco, loc.cit.n.60 at 84. 
ing, in a way, the object of an appeal against the four Judgements, seeing that the Court is expressly invited to pronounce, in its Opinion, which will be 'binding', upon the validity of these Judgements". ${ }^{65}$ The ICJ stated, however, that "a rule determining the action to be taken by [the Executive Board] on the Opinion" is an internal rule of the organization which created the ILOAT and such internal rule would in no way bar the ICJ from complying with the Request for an Opinion. ${ }^{66}$

Article XII applies only to the Executive Board of the organization concerned that "challenges a decision of the Tribunal confirming its jurisdiction" or that considers that "a decision of the Tribunal is vitiated by the a fundamental fault in the procedure followed". It is not available at all to any staff member applicant-party to the case. The advisory proceedings under Article XII thus presents "a certain absence of equality between Unesco and the officials both in the origin and in the progress of these proceedings". ${ }^{67}$ On equality in point of origin, the ICJ referred to "generally accepted practice" which requires "legal remedies against a judgment" to be equally open to either party, and said that "each possesses equal rights for the submission of its case to the tribunal called upon to examine the matter". The ICJ nevertheless ruled that the inequality in law arising from Article XII did not "in fact contribute an inequality before the Court" because "it is antecedent to the examination of the question before the Court". ${ }^{68}$ Plainly, Article XII was designed to protect the interests of effective elites of the organization concerned. Nevertheless, the ICJ averted the issue by stating that it "is not called upon to consider the merits of such a procedure or the reasons which led to its adoption". ${ }^{69}$

As the challenge raised against the ILOAT's judgements "refer[s] to the jurisdiction of the Administrative Tribunal and to the validity of the Judgements", ${ }^{70}$ the Unesco Court stated in unequivocal terms that:

"The Request for an Advisory Opinion under Article XII is not in the nature of an appeal on the merits of the judgement. It is limited to a challenge of the decision of the Tribunal confirming its jurisdiction or to cases of fundamental fault of procedure. Apart from this, there is no remedy against the decisions of the Administrative Tribunal. A challenge of a decision confirming jurisdiction cannot properly be transformed into a procedure against the manner in which jurisdiction has been exercised or against the substance of the decision." ${ }^{\text {"71 }}$ [Emphasis added]

\footnotetext{
${ }^{65}$ Ibid.

${ }^{66}$ Ibid. See ROBERTO AGO, “'Binding' advisory opinions of the International Court of Justice", 85 AJIL (1991) 439, 442.

${ }^{67}$ Ibid. at 83 . See LEO GROSS, "Participating of ïndividuals in advisory proceedings before the International Court of Justice: Question of equality between the parties", 52 AJIL (1958) 16.

${ }^{68}$ Unesco, loc.cit.n.60 at 85.

${ }^{69}$ Ibid.

${ }^{70}$ Ibid. at 83 .

${ }^{71}$ Ibid. at $98-99$.
} 
Accordingly, the Unesco Court ruled that "[t]he reasons given by the [ILO] Tribunal for its decision on the merits, after it confirmed its jurisdiction, cannot properly form the basis of a challenge to the jurisdiction of the Tribunal" because the question submitted to the Unesco Court "is concerned only with a challenge of a decision confirming jurisdiction. It does not refer to the other ground of challenge provided for in Article XII, namely a fundamental fault in the procedure followed". ${ }^{72}$ Nevertheless, echoing its earlier formulation in $E f$ fect of Awards, the Unesco Court stated: "The Statute of the Administrative Tribunal could have provided for other grounds for challenging the decision of the Tribunal than those referred to in Article XII. It has not done so". (emphasis added ${ }^{73}$ The ICJ in effect suggested in Unesco that it was prepared to play a role of an appellate court of IATs so long as the statutes of IATs provided appropriate grounds for nullity and review and that the organization concerned, be it an organ of the United Nations or a specialized agency, could stipulate grounds for review or appeal. ${ }^{74}$

To date, Unesco is the only review of a judgement of the ILOAT, but as it was the first review case of IAT judgements, it has, since then, largely shaped the reasoning of the ICJ as demonstrated below with respect to the reviews of UNAT cases. Nevertheless, despite the subsequent confusion created by the ICJ's review cases, it is clear that the Unesco Court dealt with the particular legal regime of the ILOAT, demonstrably different from the legal regime of the UNAT.

\subsection{United Nations}

In the wake of Effect of Awards, by resolution of December 17, 1954, the General Assembly of the United Nations undertook to amend the UNAT Statute with a view to "the establishment of procedure for review of the judge-

\footnotetext{
${ }^{72}$ Ibid. at 99.

${ }^{73}$ Ibid. In 'Effect of Awards', the ICJ observed: "In order that the judgments pronounced by such a judicial tribunal could be subjected to review by any body other than the tribunal itself, it would be necessary, in the opinion of the Court, that the statute of that tribunal or some other legal instrument governing it should contain an express provision to that effect. The General Assembly has the power to amend the Statute of the Administrative Tribunal by virtue of Article II of that Statute and to provide for means of redress by another organ. But as no such provisions are inserted in the present Statute, there is no legal ground upon which the General Assembly could proceed to review judgments already pronounced by that Tribunal." ICJ Rep.1954 at 56 .

${ }^{74}$ Unesco, loc.cit.n.60 at 98-99. Although the ICJ acknowledged that UNESCO undoubtedly had the general power to ask for an advisory opinion of the ICJ on questions within the scope of its activity, it refused to answer Question II as the question put to the ICJ was raised not in reliance upon the general power of UNESCO to ask for an advisory opinion, but in express linkage with Article XII of the ILOAT Statute and the question put to the ICJ was outside the orbit of Article XII. Ibid. at 99. See also SHABTAI ROSENNE, The law and practice of the International Court (rev.2nd ed.1985) 689-90, 718-19.
} 
ments of the Administrative Tribunal" and accepted, in principle, judicial review of judgements of the UNAT ${ }^{75}$ The following year the General Assembly amended the UNAT Statute by adding new Articles 11 and 12 on the basis of the report of the Special Committee on Review of the Administrative Tribunal Judgements. ${ }^{76}$ New Article 12, in line with a traditional formulation, provides for revision by the UNAT itself upon discovery of a new fact. A provision for revision on the basis of the discovery of a new fact has since been incorporated in a large number of statutes of other IATs. ${ }^{77}$ New [but now deleted] Article 11, however, was an entirely different matter. It introduced a supervisory jurisdiction by an external authority as explained at the onset. ${ }^{78}$

Eighteen years after Article 11 was adopted, the ICJ was called upon for the first time to consider a request for an opinion made under the procedure laid down in Article 11 in Application for Review of Judgement No. 158 of the United Nations Administrative Tribunal (Fasla) ${ }^{79}$ In light of the doubts expressed during the debates in the Special Committee and in the Fifth Committee of the General Assembly regarding the legality of the use of the advisory jurisdiction for the review of judgements of the UNAT, the ICJ examined first its competence to give an opinion and the propriety of its doing so in Fasla.

With respect to the ICJ's competence to give an opinion, the ICJ considered the question that, its contentious jurisdiction being limited by Article 34 of its Statute to disputes between States, the advisory jurisdiction might not be used for the judicial review of contentious proceedings which had taken place before other tribunals and to which individuals were parties. It said that "the existence, in the background, of a dispute the parties to which may be affected as a consequence of the Court's opinion, does not change the advisory nature of the Court's tasks, which is to answer the questions put to it with regard to a judgement", ${ }^{80}$ and that "[t]he mere fact that it is not the rights of States which are in issue in the proceedings cannot suffice to deprive the Court of a competence expressly conferred on it by its Statute". ${ }^{81}$

While the ILOAT Statute denies the staff member access to the review process, Article 11, paragraph 1, of the UNAT Statute allowed not only the staff member, who was a direct party to the case, but also any member State which was not a party to the case nor privy to the original proceedings before the UNAT a locus standi in the review process. The Fasla Court dismissed the

\footnotetext{
${ }^{75}$ UNGA Res.888 (IX).

${ }^{76}$ UNGA Res.957 (X) of 8 November 1955 (A/3016).

${ }^{77}$ See, e.g., Art.XI para.1 of the ADBAT Statute: "A party to a case in which a judgment has been delivered may, in the event of the discovery of a fact which by nature might have had a decisive influence on the judgment of the Tribunal and which at the time the judgment was delivered was unknown both to the Tribunal and to that party, request the Tribunal, within a period of six months after that party acquired knowledge of such fact, to revise judgment."

${ }^{78}$ See text accompanying n. 9 supra.

${ }^{79}$ ICJ Rep.1973: 167.

${ }^{80}$ Ibid. at 172 , para. 14 .

${ }^{81}$ Ibid.
} 
issue as being "without relevance to the present proceedings", but acknowledged that "close examination by the Court" would be called for if there would be an application from a member state in the future. ${ }^{82}$

In Application for Review of Judgement No. 273 of the United Nations Administrative Tribunal ${ }^{83}$ (Mortished), the first Advisory Opinion rendered under Article 11 of the UNAT Statute by an application by a member state, Mr. MORTISHED contended that the procedure

"allowing a third party to raise objections to a judgement in which it has no legal right or interest and to seek a review of that judgement is contrary to fundamental principles of the judicial process." ${ }^{\prime 4}$

The Mortished Court answered that the request for an Advisory Opinion did not emanate from a member State; therefore, it was not tantamount to intervention in the review process by an entity which was not a party to the original proceedings. Such answer may be referred to as structural formalism. It contended:

"[O]nce the Committee [on Application for Review of Administrative Tribunal Judgements] decided that there is a substantial basis for the application, the request for advisory opinion comes from the Committee and not from the member State. The origin of the application which the Committee has to consider, be it the initiative of a member State, of the Secretary-General or of a staff member party to the judgement in question, does not affect the formal origin of the request submitted to the Court: it is always from the Committee that this request emanates." 85

Thus, the Mortished Court ruled that as the request for an Advisory Opinion came from the Committee, it was not "an intervention, at review level, of a member State and hence of a third person in relation to the original proceedings" ${ }^{86}$ Such reply from the ICJ, it is submitted, is less than persuasive and candid. It entirely glossed over the reasons and circumstances under which the General Assembly amended the UNAT's Statute in 1955 despite the arguments against the propriety of a member state challenging the judgement in a dispute to which it was not a party. With the full knowledge of such arguments, the General Assembly nevertheless purposefully amended the UNAT's Statute in order to permit an intervention by a member state in a dispute between the Secretary-General and a staff member. It was an act of recognition by the General Assembly, to quote Judge LACHS, that "a member State, as a representative of the Organization, can have a legitimate interest in questioning the Tribunal's

\footnotetext{
${ }^{82}$ Ibid. at 178, para. 31.

${ }^{83}$ ICJ Rep. 1982: 325.

${ }^{84}$ Quoted in ibid. at 335, para. 24.

${ }^{85}$ Ibid.

${ }^{86}$ Ibid. at 336, para. 24.
} 
decision on a matter concerning the staff member's rights and obligations vis- $\grave{a}$ vis his ultimate employer, the Organization" ${ }^{87}$ Plainly, Article 11 was not introduced into the UNAT Statute exclusively, or even primarily, to provide "judicial protection for officials". ${ }^{88}$ As Judge LACHS stated, "the Court must therefore give due weight to the other party deserving judicial protection namely, the Organization" ${ }^{89}$ It simply underscores that the Secretary-General, as stated by the ICJ in Effect of Awards, is at all times subject to the control of the General Assembly in staff matters. ${ }^{90}$

As Article 11 clearly reflected the reconfiguration of authority and control, the Mortished Court could not cross its own ambit of control beyond which its own effectiveness would be imperilled, despite the numerous irregularities pointed out by the Mortished Court itself with respect to the composition of the UNAT, the procedures followed in the Committee, and the application of the United States to the Committee. The Mortished Court thus held the view that it should comply with the request even though "the irregularities which feature through the proceedings in the present case could well be regarded as constituting compelling reasons for a refusal by the Court to entertain the request". ${ }^{91}$ The Mortished Court reasoned:

\begin{abstract}
"The stability and efficiency of the international organizations, of which the United Nations is the supreme example, are however of such paramount importance to world order, that the Court should not fail to assist a subsidiary body of the United Nations General Assembly in putting its operation upon a firm and secure foundation. While it would have been a compelling reason, making it inappropriate for the Court to entertain a request, that its judicial role would be endangered or discredited, that is not so in the present case, and the Court thus does not find that considerations of judicial restraint should prevent it from rendering the advisory opinion requested. In the present case such a refusal would leave in suspense a very serious allegation against the Administrative Tribunal, that it had in effect challenged the authority of the General Assembly." 92
\end{abstract}

\footnotetext{
${ }^{87}$ Ibid. at 413, para. 9 (dissenting opinion of Judge LACHS).

${ }^{88}$ ICJ Rep.1973 at 183, para.40. The Secretary-General's Report on Review of the Procedure provided for under Article 11 of the Statue of the Administrative Tribunal of the United Nations, UN Doc.A/C.6/49/2, at para.35, was more explicit: "[T]he review procedures for Tribunal judgements were not established primarily for the purpose of giving applicants, or even executive heads, another level of appeal. Its purpose was rather to enable States to challenge judgements that they considered for some reason as unacceptable and to do so before the principal judicial organ of the United Nations, rather than in a representative body such as the General Assembly of the United Nations in which the decisions of a subsidiary organ such as a tribunal might well be set aside on essentially political considerations." [emphasis added.]

${ }^{89}$ ICJ Rep.1982 at 413, para. 10 (dissenting opinions of Judge LACHS).

${ }^{90}$ ICJ Rep.1954 at 60.

${ }^{91}$ ICJ Rep. 1982 at 347, para.45.

${ }^{92}$ Ibid.
} 
Judge LACHS referred to the irregularities committed at the stage of the Committee on Applications as 'most striking'. ${ }^{93}$ When the procedural irregularities were so striking and numerous, they could not ipso facto have met "the requirements of the judicial process", as the Mortished Court itself observed, which was "essential for the Court's decision as to what response it will make to the request for advisory opinion" ${ }^{94}$ Nonetheless, the Mortished Court complied with the request because the reply of the ICJ represents "its participation in the activities of the Organization and, in principle, should not be refused". ${ }^{95}$

\subsection{The role of the ICJ as an appellate court under the former legal regime of the UNAT}

Compared with Article XII of the ILOAT Statute, Article 11 of the UNAT Statute provided two additional grounds of objection to a judgement to the UNAT: (i) the UNAT had failed to exercise jurisdiction vested in it; and (ii) the UNAT erred "on a question of law relating to the provisions of the UN Charter". From a standpoint of expanding the ICJ's review function, most important was the latter ground of an error on a question of law relating to the provisions of the UN Charter. It, in effect, authorized the ICJ to function as an appellate court to the UNAT "to review the actual substance of the SecretaryGeneral's decision and, if necessary, to substitute its own opinion on the merits for that of the UNAT" ${ }^{96}$

The Committee on Applications for Review of Administrative Tribunal Judgements which exercised an initial screening power to determine whether "there is a substantial basis for the application" under Article 11, paragraph 2, of the UNAT Statute was composed of "the Member States the representatives of which have served on the General Committee of the most recent regular session of the General Assembly". The General Committee consists of one Chairman and 27 members: The President of the General Assembly, as Chairman, the 21 Vice-Presidents of the General Assembly and the Chairmen of the

\footnotetext{
${ }^{93}$ Ibid. at 411, para. 3 (dissenting opinion of Judge LACHS).

${ }^{94}$ Id. at 335 , para. 23.

${ }^{95}$ Interpretation of Peace Treaties (Advisory Opinion), ICJ Rep.1950 at 71. Under Article 11, paragraph 3, of the UNAT Statute, the Secretary-General had to give effect to the ICJ's opinion or the UNAT had to act to confirm its original judgement or give a new judgement, "in conformity with the opinion of the Court". The opinion of the ICJ was thus to be given "a reformatory character". It was "the distinctly appellate character of the function". Under deleted Article 11 of the UNAT Statute, the ICJ was the final authority on interpretation of the UN Charter or of staff regulations based on the Charter. GROSS, loc.cit.n.67 at 36. As the ICJ stated in Fasla, "the opinion given by the Court is to have conclusive effect with respect to the matters in litigation" in the case before the UNAT and such was a "special effect to be attributed to the Court's opinion by Article 11" of the UNAT Statute. ICJ Rep.1973 at 182-183, para.89.

${ }^{96}$ Application for Review of Judgment No. 333 of the United Nations Administrative Tribunal, ICJ Rep.1987: 4, 89, at para.15 (separate opinion of Judge ODA).
} 
six Main Committees of the General Assembly as members, who are all politically elected. As the ICJ later remarked, "being composed of member States, the committee is a political organ", and it nevertheless discharged "functions which, in the Court's view, are normally discharged by a legal body" ${ }^{97}$ Thus, the ICJ considered the review procedure under Article 11 not to be "free from difficulty". ${ }^{98}$

The procedural difficulty in Article 11 of the UNAT Statute notwithstanding, the ICJ complied with the request for an advisory opinion under Article 11 because its refusal would deprive officials of "the judicial protection" in the form of a judicial review provided in the UNAT Statute "precisely in those cases in which the Committee has found that there is a substantial basis for the objections which have been raised against a judgement". ${ }^{99}$ It is pertinent to recall at this juncture the ICJ's opinion in Effect of Awards that:

"[s]hould the General Assembly contemplate, for dealing with future disputes, the making of some provision for the review of the awards of the Tribunal, the Court is of opinion that the General Assembly itself, in view of its composition and functions, could hardly act as a judicial organ--considering the arguments of the parties, appraising the evidence produced by them, establishing the facts and declaring the law applicable to them--all the more so as one party to the disputes is the United Nations Organization itself." 100

As it was the Committee, a twenty-eight member political organ, that formulated the question to be put to the ICJ,

"the framing of questions to be put to the Court is often tinged with meta-legal conceptions of particular State Members of the Committee, which are often reflected in the manner of the categorization of the questions to be asked of the Court. The result has often been to make the question in the end either irrelevant or patently obscure." 101

Nevertheless, the ICJ concluded that questions to be put to the ICJ by the Committee would arise in the course of performing its primary function of screening the applications presented to it under Article 11 of the UNAT Statute, and "that there is no necessary incompatibility because the exercise of these functions by a political body and the requirements of the judicial process, inasmuch as these functions merely furnish a potential link between two procedures which are clearly judicial in nature". ${ }^{102}$

\footnotetext{
${ }^{97}$ ICJ Rep.1973 at 176, para. 25.

${ }^{98}$ Id. at 183 , para. 40.

${ }^{99}$ Id. at 177 , para. 28.

${ }^{100}$ ICJ Rep. 1954 at 56.

${ }^{101}$ ICJ Rep. 1987 at 18, 78.

${ }^{102}$ ICJ Rep. 1973 at 176, para.25.
} 
"They are therefore questions which, in the view of the Court, arise within the scope of the Committee's own activities; for they arise not out of the judgements of the Administrative Tribunal but out of objections to those judgements raised before the Committee itself." 103

By segregating questions arising "out of the judgements of the Administrative Tribunal" and questions arising "out of objections to those judgements", the ICJ underscored the nature of the advisory proceedings, in which "the task of the Court is not to retry the case" but to give its opinion on the questions submitted to it concerning the objections lodged against the judgements. ${ }^{104}$

In Fasla, the first review case of a judgement of the UNAT after Unesco, which was an ILOAT case, the ICJ demonstrated the crucial difference between the legal regime of the ILOAT and that of the UNAT. In the legal regime of the ILOAT, the ICJ held that the distinction between jurisdiction and merits is of great importance because any mistakes with regard to jurisdiction can be corrected by the ICJ on a Request for an Advisory Opinion emanating from the Executive Board, but errors of fact or of law on the part of the ILOAT in its Judgements on the merits cannot give rise to review by the ICJ.

It is critical to recall that in Fasla, the ICJ was dealing with the same two grounds of objection, i.e., "jurisdiction" and "a fundamental fault in the procedure followed" under the ILOAT Statute or "jurisdiction" and "fundamental error in procedure" out of the four grounds of objection laid down in the UNAT Statute. The jurisprudence resorted to by the Fasla Court was the same as the Unesco Court even though these two cases originated from the different legal regimes of two separate Statutes concerned. ${ }^{105}$ Thus, the Fasla Court's reasoning that "[u]nder Article 11 of the Statute of the Tribunal ... the task of the Court is not to retry the case but to give its opinion on the questions submitted to it concerning the objections lodged against the Judgement" was consistent with the Unesco Court's reasoning. Within that purview limited by the questions submitted to the ICJ, the Fasla Court was correct to state that it was not therefore "entitled to substitute its own opinion for that of the Tribunal on the merits of the case adjudicated by the Tribunal" ${ }^{106}$ because the ICJ was not

\footnotetext{
${ }^{103}$ Ibid. at 174 , para. 21 .

${ }^{104}$ Ibid. at 182, 38 and 187, 47. Cf. The Arbitral Award Made by the King of Spain on 23 December 1906, loc.cit.n.28 at 214: "[T]he Award is not subject to appeal and ... the Court cannot approach the consideration of the objections raised by Nicaragua to the validity of the Award as a Court of Appeal. The Court is not called upon to pronounce on whether the arbitrator's decision was right or wrong. These and cognate considerations have no relevance to the function that the Court is called upon to discharge in these proceedings, which is to decide whether the Award is proved to be a nullity having no effect."

${ }^{105}$ Ibid. at 188, para. 48. The Fasla Court, referring to the Unesco Court, likewise held that "under Article 11 of the Statute of the United Nations Administrative Tribunal a challenge to a decision for alleged failure to exercise jurisdiction [or] fundamental error in procedure cannot properly be transformed into a proceeding against the substance of the decision." Ibid. (emphasis added.)

${ }^{106}$ Ibid. at 187-88, para.47.
} 
required to act on a genuine appeal, but "to give a reply to legal questions framed by an extraneous body which may well, and in fact in all cases, divert the Court from a discussion of the real problems". ${ }^{107}$

The Fasla Court, however, underscored the difference from the legal regime of the ILO Tribunal:

"This does not mean that in an appropriate case, where the judgement has been challenged on the ground of an error on a question of law relating to the provisions of the Charter, the Court may not be called upon to review the actual substance of the decision [emphasis added]." 108

The review authority conferred upon the ICJ under the UNAT Statute in so far as an error of law relating to the Charter provisions was alleged was, to quote Judge SCHWEBEL, "designedly and decisively wider" than that which applies under Article XII of the ILOAT Statute. ${ }^{109}$ The ICJ's role was to determine if the circumstances of the case, "whether they relate to merits or procedure", showed that any objection made to the judgement on one of the grounds stipulated in Article 11(1) was well founded. It was "not limited to the contents of the challenged award itself", but must have considered "all relevant aspects of the proceeding before the Tribunal as well as all relevant matters submitted to the Court itself by each party to the case with respect to the objections raised against that judgement". ${ }^{110}$ The ICJ thus held that "where the judgement has been challenged on the ground of an error on a question of law relating to the provisions of the Charter, the Court may ... be called upon to review the actual substance of the decision" 111 and that, in reviewing proceedings, the ICJ was not "precluded from examining in full liberty the facts of the case" 112 [emphasis added]. As an objection on this ground related not to the validity of the judgement but to the merits of the judgement, the ICJ, when seized of a case of this kind, exercised "judicial review, a true appellate jurisdiction". ${ }^{113}$

The Fasla Court suggested that if "the grounds of objection upon which the present proceeding are based" are the substantive ground of objection, the Court would act "as a court of appeal". ${ }^{114}$ The Mortished Court on the other

\footnotetext{
${ }^{107}$ PESCATORE, loc.cit.n. 16 at 231.

${ }^{108}$ ICJ Rep. 1973 at 188 , para. 48.

${ }^{109}$ ICJ Rep.1982 at 478, para.33 (dissenting opinion of Judge SCHWEBEL).

${ }^{110}$ ICJ Rep.1973 at 188, para.47.

${ }^{111}$ Ibid. at 188 , para. 48 .

${ }^{112}$ Ibid. at 207, para.85.

${ }^{113}$ GROSS, loc.cit.n.67 at 36.
}

114 "If the Court were acting in this case as a court of appeal, it might be entitled to reach its won conclusions as to the amount of the damages to be awarded, but this is not the case. In view of the grounds of objection upon which the present proceedings are based, . . . the Court must confine itself to concluding that there is no such unreasonableness in the award as to make it fall outside the limits of the tribunal's discretion. This being so, the Tribunal cannot be considered as having failed to exercised its jurisdiction in this respect”. ICJ Rep.1973 at 197, para. 65 (emphasis added). See also ICJ Rep.1982: 454, 481, para. 37 (dissenting opinion of Judge 
hand rhetorically asked itself about "the proper role of the Court when asked for an advisory opinion in respect of this ground of objection", and eschewed an answer by stating:

"There are ... other reasons, some of them especially compelling in the present case, why the Court should not attempt by an advisory opinion to fill the role of a court of appeal and to retry the issues on the merits of this case as they were presented to the Tribunal." 115

The Mortished Court listed "the difficulties of using the advisory jurisdiction of the Court for the task of trying a contentious case, and especially one to which one of the parties is an individual", ${ }^{116}$ but failed to mention the Fasla Court's reasoning in complying with the request for an opinion. Instead, the Mortished Court reopened the argument that the interposition of the Committee between the Administrative Tribunal and the proceedings before the Court would be "unacceptable if the advisory opinion were to be assimilated to a decision on appeal". ${ }^{117}$ The Mortished Court, while attributing the ruling of the Fasla Court to "the assumption that the proceedings before the Court were not to retry, on appeal, the same issue as that tried by the Administrative Tribunal", ${ }^{118}$ overstated that Fasla Court's assumption. ${ }^{119}$ If the rationale of Falsa were followed, the Mortished Court could have acted, as later remarked by Judge ODA in his separate opinion in Application for Review of Judgement No. 333 of the United Nations Administrative Tribunal ${ }^{120}$ (Yakimetz), "to function in

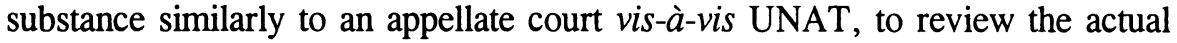
substance of the Secretary-General's decision and, if necessary, to substitute its own opinion on the merits for that of UNAT". ${ }^{121}$

Despite the initial thrust of the ICJ's reasoning developed both in Unesco and Fasla, the ICJ had restrained itself in all the subsequent cases, i.e., Mor-

\footnotetext{
SCHWEBEL).

${ }^{115}$ ICJ Rep.1982 at 356, para. 58.

${ }^{116}$ Ibid. at 356, para. 59.

${ }^{117}$ Ibid. at 357, para. 60 .

${ }^{118}$ Ibid.

${ }^{119}$ The Fasla Court, in fact, ruled that "the task of the Court is not to retry the case but to give its opinion on the questions submitted to it concerning the objections lodged against the Judgement. The Court is not therefore entitled to substitute its own opinion for that of the Tribunal on the merits of the case adjudicated by the Tribunal. Its role is to determine if the circumstances of the case, whether they relate to merits or procedure, show that any objection made to the Judgement on one of the grounds mentioned in Article 11 is well founded. In so doing, the Court is not limited to the contents of the challenged award itself, but takes under its consideration all relevant aspects of the proceedings before the Tribunal as well as all relevant matters submitted to the Court itself by the staff member and by the Secretary-General with regard to the objections raised against that judgement. These objections the Court examines on their merits in the light of the information before it." [emphasis added] ICJ Rep.1973 at 187-188, para.47.

${ }^{120}$ ICJ Rep. 1987: 18.

${ }^{121}$ Ibid. at 89, para. 15.
} 
tished of 1982 and Yakimetz of 1987, where the ICJ could have exercised judicial review in the role of an appellate court. The Mortished Court validated an unsustainable claim of 'acquired rights' to a repatriation grant admitted by the UNAT and the Yakimetz Court failed to address the essential question involved in the Application: is 'secondment' compatible with Article 100 of the UN Charter? The ICJ's apparent inability to tackle the real problems presented by these cases is rooted in the majority judges' own doubt about the role of the ICJ. Judge AGO, for example, has confessed that he 'cannot help feeling' that these requests for review "place the Court in an uncomfortable situation" ${ }^{122}$ and has concluded that "the Court has very little scope for exercising any decisive concrete influence in the interest of ensuring that administrative justice is genuinely done". ${ }^{123}$ Such attitude has rendered the ICJ unable to "face its responsibility, coming down from the height of its Byzantine rationalizations to the true work of international administration". ${ }^{124}$

It must be borne in mind, however, that judicial review of judgements of IATs by the ICJ is only made possible under Article 96 of the UN Charter which provides to the United Nations and specialized agencies access to the ICJ for advisory opinions. Since many IATs such as ADBAT are outside the orbit of the United Nations system or the specialized agencies of the United Nations, either the administrator of these organizations or their staff cannot seek a review of any judgement of their IATs nor can they invoke a broader supervisory jurisdiction of an external institution. What can they do?

\section{REVIEW OF THE TAX REIMBURSEMENT CASE}

The Asian Development Bank faced that dilemma when the judgement in Ferdinand P. Mesch and Robert Y. Siy v. the Asian Development Bank was rendered by the ADBAT on 8 January 1994 (Mesch I). ${ }^{125}$ The ADBAT held, inter alia, that "[i]n principle, the terms and conditions of employment of the Applicants entitle them to reimbursement . . . of income tax levied and paid on their salaries". ${ }^{126}$ The ADBT stated that:

\footnotetext{
${ }^{122}$ Ibid. at 107, para. 4 (separate opinion of Judge AGO).

${ }^{123}$ Ibid. at 108.

${ }^{124}$ PESCATORE, loc.cit.n.16 at 237.

${ }^{125}$ Decision No.2. I acted as principal counsel in all the proceedings relating to Ferdinand $P$. Mesch and Robert Y. Siy v. the Asian Development Bank (No.2) of 31 March 1995 (Mesch I), Decision No.2, 1 ADBAT Rep.21; Ferdinand P. Mesch and Robert Y. Siy v. Asian Development Bank (No.2) of 31 March 1995 (Mesch II), Decision No.6, 1 ADBAT Rep.67; Ferdinand P. Mesch and Robert Y. Siy v. the Asian Development Bank (No. 3) of 13 August 1996 (Mesch III), Decision No.18, 2 ADBAT Rep.117; and Ferdinand P. Mesch and Robert Y. Siy v. the Asian Development Bank (No. 4) of 7 August 1997 (Mesch IV).

${ }^{126}$ Ibid. at 16 .
} 
"The Charter, Bylaws, and Board Resolutions did not establish any obligation of the Bank in respect of the reimbursement of income tax levied on staff salaries; equally however, those documents did not prohibit the adoption of any such obligation. Likewise, although the letters of appointment issued by the Bank to professional staff did not include any express undertaking to reimburse income tax, nevertheless they did not specifically exclude that prospect. There was thus no pronouncement by the Bank as to the exclusion of tax reimbursement.

In balancing in the present case the equities as between the Bank and its staff, the Tribunal considers that more weight should be given to the interests of the employee than to those of the employer, if only because the Bank could have so structured its terms of employment as to exclude expressly the prospect of equal pay for comparable work and could thus have excluded the need for tax reimbursement. But it never did so. Any ambiguity or uncertainty in this respect, wherever appearing in documents emanating from the Bank, must therefore, be resolved contra proferentem and in favor of the staff." 127

The ADBT therefore required the Bank to reimburse Applicants and other similarly situated staff for the taxes paid on their salaries derived from the Bank "upon a reasonably prompt claim being made, accompanied by proof of payment of such tax" ${ }^{128}$ This authoritative decision handed down by the ADBAT posed a serious challenge to the process of effective decision as it was then constituted, because the Bank had never reimbursed any income tax levied and paid by any staff members since the inception of the Bank in 1966. Not only did Mesch I defy the expectations held by the effective power holders of the Bank, it caused the initiation of a process of review, which ultimately led to the repudiation of that decision. The dilemma of the Bank was, however, fundamental to the review of the judgement of the ADBAT, which was 'final and binding' without appeal.

The ADBAT itself was established in 1991 as an independent judicial body to settle disputes between staff members and the organization. The integrity and judicial authority of the ADBAT must be maintained in order to foster the morale of Bank staff. If the authority of the ADBAT were tampered with by effective power, the integrity and independence of the ADBAT, the very base on which the ADBAT's authority rests, would be utterly weakened. Thus, finality and review appeared irreconcilable.

"[N]ullification and review are not governed solely by the exigencies of effective power. If an authoritative process is sustained by effective elites because it serves their interests, the impulse to nullify a particular authoritative decision will be counteracted to some extent by their long-range interest in continuing that authoritative process of decision. As the probability of damage to processes

\footnotetext{
${ }^{127}$ Ibid. paras 14 \& 17.

${ }^{128}$ Ibid. at para. 22.
} 
of authority by a nullification increases, a parallel impulse to limit the review and its effects emerges." 129

Subsequent to the Mesch I, therefore, the Board of Directors of ADB, upon a careful review of the decision and the issue of tax reimbursement, adopted, on 6 October 1994, a resolution (Resolution) which expressly stated that "the Bank shall discharge its obligations under the Statute of the Administrative Tribunal of the Asian Development Bank in connection with Decision No. 2." At the same time the Resolution reaffirmed the Bank's long-standing practice of non-reimbursement of taxes and provided that the Bank shall not reimburse the taxes paid by any Governor, any Director, any Alternate, the President, any Vice President and any staff member of the Bank for the taxes paid by them in respect of their salaries and emoluments from the Bank, effective upon the date of the Resolution.

The Resolution explicitly mentioned "the Bank's choice actually made and consistently enforced" not to reimburse for the income tax levied and paid by its staff members, and reaffirmed the Bank's "long-standing practice of no reimbursement of taxes". Further, the Board of Directors in the Resolution confirmed the Bank's commitment to the principle of equal pay for comparable work and further clarified that, in accordance with the Bank's consistent practice, this principle would apply to salaries and emoluments before the imposition of any tax. Thus, the Resolution simply expressed what had always been the policy and the practice of the Bank.

Subsequent to the adoption of the Resolution, the lawfulness of the Resolution was challenged by the staff members concerned in Ferdinand P. Mesch and Robert Y. Siy v. the Asian Development Bank (No. 3) ${ }^{130}$ (Mesch III). As the ADBT remarked

"Although some terms and conditions of employment can be prospectively altered, the principle that fundamental and essential terms and conditions of employment cannot unilaterally be amended is now a recognized principle which can be regarded as part of the law common to international organizations. That principle imposes a limitation on the powers of the governing bodies of every international organization, restraining the unilateral amendment of such terms and conditions. Without deciding whether that principle could have been excluded by the provisions of the Charter of the Bank, it suffices to note that the Charter does not do so, and therefore the powers of the Board of Governors and of the Board of Directors of the Bank are subject to that limitation. However, when the Bank was founded there was no institution which was empowered to compel the Bank to comply with that principle. And when the Statute of the Tribunal was adopted, that limitation already existed: it was not one imposed or deemed to have been imposed by the Statute. The Tribunal was given jurisdiction in respect of complaints by staff members alleging non-observance of their

\footnotetext{
${ }^{129}$ REISMAN, op.cit.n.27 at 72.

${ }^{130}$ Decision No.18, 2 ADBAT Rep. 117.
} 
contracts of employment and terms of appointment. That Statute does not prescribe any pertinent exception or qualification in respect of the jurisdiction of the Tribunal, and so that jurisdiction extends to non-observance of contractual terms resulting from the infringement of that principle."131

The ADBAT thus concluded that "it has competence to consider whether a decision of the Bank embodied in a Resolution of the Board of Directors is a nullity because it purports unilaterally to amend a fundamental and essential term or condition of employment". ${ }^{132}$

The tax reimbursement case litigated successively over the years culminated in Ferdinand P. Mesch and Robert Y. Siy v. the Bank (No. 4) of 7 August $1997^{133}$ (Mesch IV) in which, to quote a passionate dissenting opinion of Professor BRIGITTE STERN, "the Tribunal has de facto overruled one of its decisions in such a way, without saying so". ${ }^{134}$ The ADBT stated that "it can ... hardly be said under the facts of this case that tax reimbursement was reasonably assumed by staff members to be central to their contract of service or that they had a reasonable expectation of its continuation, in light of the fact that the Bank, over the decades since its formation in 1966, had never implemented such a benefit". ${ }^{135}$ It also stated that "the Tribunal did not consider tax reimbursement to be an intrinsically fundamental term which could not have been excluded". ${ }^{136}$ Moreover, the ADBT stated it had not decided in Mesch I that "tax reimbursement is always a corollary of 'equal compensation for equal work,' or is inextricably intertwined with external comparison with the IBRD". 137

With respect to the principle of equal compensation for equal work, the ADBT explained that the principle means "equal pay for work of equal value" and "the application of the principle involves only a consideration of the 'value' of the work to the employer". ${ }^{138}$ The ADBT accordingly held that "the employer's obligation to treat its employees equally does not extend to remedying discrepancies created by the conduct of the State of which the employee is a citizen". 139

Professor BRIGITTE STERN lamented in her dissenting opinion that "the Tribunal has endorsed, through what [she] personally consider[s] a painstaking and contradictory legal reasoning, the Bank's 6 October 1994 Resolution whose

\footnotetext{
${ }^{131}$ Ibid. at para. 22.

${ }^{132}$ Ibid. at para.24. This is in accord with de Merode, WBAT Rep.[1981] Decision 1. The ADBAT's conclusion stands in sharp contrast with the Statute of the IMF Administrative Tribunal which limits its own jurisdiction. See AMERASINGHE, loc.cit.n.45 at 785-786.

${ }^{133}$ Decision No. 35 of 7 August 1997.

${ }^{134}$ Ibid. Dissenting Opinion of Professor STERN, at para. 3.

${ }^{135}$ Ibid. at para. 24.

${ }^{136}$ Ibid. at para. 28.

${ }^{137}$ Ibid. at para. 34 .

${ }^{138}$ Ibid. at para. 30.

${ }^{139}$ Ibid.
} 
avowed purpose was to eliminate for the future the normal consequences that were to flow from one of its decisions. ${ }^{140}$ Indeed, the opinion in Mesch IV shows a 'painstaking' analysis in its effort to stay within the rationale of Mesch $I$, but in effect to reverse Mesch $I$ in light of the Resolution under which the issue before Mesch $I V$ was "whether the obligation to reimburse tax is a fundamental and essential condition of employment." ${ }^{141}$ The ADBAT held in a 3-2 split decision "that reimbursement of national income taxes is not a fundamental and essential condition of employment; that the Bank therefore had the power unilaterally to amend the condition as to tax reimbursement; and that the Board of Directors Resolution was valid." 142

It is a truism that every decision, once made, is subject to review. Although review takes a variety of forms, it is not easy for any decision-maker to repudiate his or her own decision previously made. It would be much less painful for another institution to overturn a decision made by somebody else. Selfscrutiny or self-censorship is a most difficult function to discharge. Objectivity perforce requires mental and intellectual detachment from the subject matter under review.

\section{TOWARD THE FUTURE}

The review and repudiation of judgments of IATs were necessarily triggered by the interests of the organization concerned, first as evidenced by the ILO Tribunal's amended Statute. Thus, even the abolishment of the review procedure provided under Article 11 of the Statute of the UN Tribunal notwithstanding, the Secretary-General's Report alluded to the need for "Member States to seek an advisory opinion" ${ }^{143}$ of the ICJ in cases where they have reason to believe that the UNAT has exceeded its jurisdiction or competence or to consider that the UNAT has erred on a question of law relating to the provisions of the UN Charter. The Report rationalized that "[t]hese two grounds do not relate to the merits of the dispute between the staff member and the Organization but relate to fundamental constitutional issues of division of powers between legislative and judiciary which is a legitimate concern of Member States". ${ }^{144}$

Such focus on the interests of member states and the organization has paid only scant attention to the unique status of a staff member as an agent under international law. He or she is not "a private person" vis-à-vis the SecretaryGeneral, "the chief administrative officer of the Organization". ${ }^{145}$ The point

\footnotetext{
${ }^{140}$ Ibid. Dissenting Opinion, at para. 3 (Professor STERN).

${ }^{141}$ Ibid. at para.16.

${ }^{142}$ Ibid. at para. 49.

${ }^{143}$ The Secretary-General's Report, loc.cit.n.88, at para.38.

${ }^{144}$ Id.

${ }^{145}$ ICJ Rep.1973: 134-38 (dissenting opinion of Judge MOROZOV).
} 
that needs to be emphasized is that international civil servants are not 'individuals' in an ordinary sense; they are a special category of individuals who enjoy the right of functional protection under international law.

\begin{abstract}
"In order that the agent may perform his duties satisfactorily, he must feel that this protection is assured to him by the Organization, and that he may count on it. To ensure the independence of the agent, and, consequently, the independent action of the Organization itself, it is essential that in performing his duties he need not have to rely on any other protection than that of the organization (save of course for the more direct and immediate protection due from the State in whose territory he may be). In particular, he should not have to rely on the protection of his own State. If he had to rely on that States, his independence might well be compromised, contrary to the principle applied by Article 100 of the Charter. And lastly, it is essential that - whether the agent belongs to a powerful or to a weak State; to one more affected or less affected by the complications of international life; to one in sympathy or not in sympathy with the mission of the agent - he should know that in the performance of his duties he is under the protection of the organization." 146
\end{abstract}

The agent's status is governed internally by the internal law of the organization which flows from Article 100 of the UN Charter and externally by the privileges and immunities accorded to him under international law. Should the organization as his employer be allowed to appeal to the ICJ, the other party to the dispute, an individual staff member, should equally be allowed to do the same. The moment the individual staff member responds to the application for review filed by the organization or a Member State in order to meet the requirement of the judicial character of the ICJ that "both sides directly affected by these proceedings should be in a position to submit their views and their arguments to the Court", ${ }^{147}$ the conventional criticism that the ICJ is not open to individuals collapses, in that whoever triggers the process, the equation is always the same.

Various proposals were made in the past ranging from the merger of the UNAT and the ILOAT to the harmonization of the two Tribunals by creating a second-tier administrative tribunal over them, but none materialized for the obvious difficulty involved in any of the proposals. ${ }^{148}$ It has been declared 'a lost cause' ${ }^{149}$ None of the proposals, however, paid attention to regional organizations which are outside the orbit of the UN system. How can we struc-

\footnotetext{
${ }^{146}$ Reparation for injuries suffered in the service of the United Nations, ICJ Rep.1949: 174, at 183-84.

${ }^{147}$ ICJ Rep. 1956 at 86.

${ }^{148}$ See, e.g., ICJ Rep. 1987 at 74-75 (declaration of Judge LACHS); ibid. at 76 (separate opinion of Judge ELIAS); ibid. at 108-09 (separate opinion of Judge AGO); RUDOLF OSTRIHANSKY, "Chamber of the International Court of Justice", 37 ICLQ (1988) 30, 52; and MANFRED LACHS, "Some reflections on the contribution of the International Court of Justice to the development of international law", 10 Syracuse JILC (1983) 239, 276-77 (1983).

${ }^{149}$ AMERASINGHE, loc.cit.n.45 at 776.
} 
ture an appeal or review process to which these non-UN system organizations can also have access?

There are four kinds of IATs. The UNAT and the ILOAT are the two principal tribunals for all international organizations under the UN system. The jurisdiction of the UNAT covers at present the United Nations, the International Civil Aviation Organization and the International Maritime Organization (the IMO) whereas the jurisdiction of the ILOAT covers all functional international organizations headquartered in Europe except the IMO ${ }^{150}$ The third kind of tribunal belongs to the international financial institutions, i.e., the World Bank Administrative Tribunal covering the IBRD, IFC, and MEGA, the InterAmerican Development Administrative Tribunal, the ADBAT, the IMF Administrative Tribunal, and the African Development Bank Administrative Tribunal. (There are proposals under consideration for a tribunal of the European Bank for Reconstruction and Development.) The fourth kind of tribunal is related to regional community-organizations such as the Organization of American States and the European Community.

As each group of IATs has developed its own jurisprudence and flavor, it would be difficult to alter the established structures of these tribunals. ${ }^{151}$ I therefore recommend the following.

Each organization should establish its own administrative tribunal within its organizational 'district' which should act as a tribunal of first instance, i.e., 'a district court', so to speak, which deals with all preliminary issues involving factual questions. Contested legal issues can be raised later on appeal to the UNAT or the ILOAT which should act as 'a Court of Appeal' for those organizations which are under the jurisdiction of either Tribunal at present. For this purpose, the UNAT and the ILOAT must create their respective tribunals of first instance, as in the case of the Court of First Instance of the Court of Justice of the European Communities, to deal with all original applications not

${ }^{150}$ The following Organizations have accepted the ILO Tribunal's Jurisdiction: World Health Organization (WHO), United Nations Educational, Scientific and Cultural Organization (UNESCO), International Telecommunication Union (ITU), World Meteorological Organization (WMO), Food and Agricultural Organization of the United Nations (FAO), European Organization for Nuclear Research (CERN), General Agreement on Tariffs and Trade (GATT), International Atomic Energy Agency (IAEA), World Intellectual Property Organization (WIPO), European Organisation for the Safety of Air Navigation (Eurocontrol), Universal Postal Union (UPU), European Patent Organisation (EPO), European Southern Observatory (ESO), Intergovernmental Council of Copper Exporting Countries (CIPEC), European Free Trade Association (EFTA), Inter-Parliamentary Union, European Molecular Biology Laboratory (EMBL), World Tourism Organization (WTO), African Training and Research Centre in Administration for Development (AFRAD), Central Office for Railway Transport (OCTI), International Center for the Registration of Serials (CIEPS), International Office of Epizootics (OIE), United Nations Industrial Development Organization (UNIDO), International Criminal Police Organization (Interpol).

151 "The two tribunals are well-established in their separate identities and it would be foolish to resume the bygone project of a possible merger." PESCATORE, loc.cit.n.16 at 236. See also ELIAS, loc.cit.n.2 at 29-33; AMERASINGHE, loc.cit.n.45 at 776-78. 
only from those organizations which do not establish administrative tribunals as their own 'district courts', but also from staff members of the United Nations or the ILO. Likewise, in the case of the financial institutions, their own respective administrative tribunals should each act as 'a district court', from which legal issues should be raised on appeal to the World Bank Tribunal which should act as 'a Court of Appeal' for all financial institutions representing 'a functional region'. The World Bank Tribunal must also create its tribunal of first instance within to deal with all the original applications from staff members of the IBRD, IFC and MIGA. Out of these 'Courts of Appeal' comes further appeal to the ICJ at the apex of this judicial hierarchy as "the principal judicial organ of the United Nations" which can "contribute in practical terms to the improvement or operation of the law within the United Nations system" ${ }^{152}$ In this way, all applications will be examined judicially in the normal system of adjudication without ever resorting to a political organ such as the Committee on Applications for Review.

Although these recommended procedures will require various amendments to the respective Statutes of the UN, ILO and World Bank Tribunals as well as to other administrative tribunal statutes, the procedure of appeal in each group of administrative tribunals will be uniformly established throughout their respective statutes of administrative tribunals, and the respective Statutes of the UN, ILO and World Bank Tribunals as they relate to the appeal or review process to the ICJ will also be fashioned uniformly in order to permit the use of the advisory function of the ICJ as a de facto appellate function. ${ }^{153}$

\footnotetext{
${ }^{152}$ ICJ Rep.1987:18 at 75 (declaration of Judge LACHS). See a critical comment offered by a judge of the ILO Tribunal: "The International Court has shown no sensitivity to [the characteristics of administrative jurisdiction, which must remain close to the facts and which requires rapid and clear decisions]. Therefore, the opinion rendered so far have remained useless pieces of legal fiction." PESCATORE, loc.cit.n.16 at 231.

${ }^{153}$ In dealing with a request for an advisory opinion the ICJ exercises its power in proper cases to determine the real meaning of the question put to it. In Interpretation of the Agreement of 25 March 1951 between the WHO and Egypt, the ICJ underscored that "if it is to remain faithful to the requirements of its judicial character in the exercise of its advisory jurisdiction, it must ascertain what are the legal questions formulated in the request”. ICJ Rep.1980: 73 at 88, para.35.
} 